\title{
Community Health Innovation through an Interprofessional Course
}

\section{Dr. Jacquelyn Kay Nagel, James Madison University}

Dr. Jacquelyn K. Nagel is an Assistant Professor in the Department of Engineering at James Madison University. She has eight years of diversified engineering design experience, both in academia and industry, and has experienced engineering design in a range of contexts, including product design, bio-inspired design, electrical and control system design, manufacturing system design, and design for the factory floor. Dr. Nagel earned her Ph.D. in mechanical engineering from Oregon State University and her M.S. and B.S. in manufacturing engineering and electrical engineering, respectively, from the Missouri University of Science and Technology. Dr. Nagel's long-term goal is to drive engineering innovation by applying her multidisciplinary engineering expertise to instrumentation and manufacturing challenges.

\section{Dr. Patrice M. Ludwig, James Madison University}

Patrice Ludwig is an Assiatant Professor of Biology at James Madison University. She earned her doctoral degree in biology from the University of Virginia. Her research interests are in understanding changes in undergraduate attitudes and knowledge as a result of work across disciplines to solve real world problems. She also studies using artificial substrates to restore and conserve oyster reefs.

\section{Dr. Erica J. Lewis}

http://www.nursing.jmu.edu/people/lewis.html 


\title{
Community Health Innovation through an Interprofessional Course
}

\begin{abstract}
The broad goal of this interdisciplinary course is to allow pre-professional biology, pre-nursing, and engineering students to leverage MakerSpace technology to produce and communicate tangible solutions to current challenges in community health. For the past two iterations of the course students developed solutions to metabolic syndrome using MakerSpace technologies (3D printing, laser cutters/engravers, virtual reality, and related software). Communication between disciplines that impact each other, but may have different biases and goals, is important. This communication is facilitated through teamwork. In the course, students receive explicit training in problem solving techniques, teamwork, and communication. For example, students form their teams using the StrengthsFinders analysis to build on the individual strengths. Moreover, the teams watch a video on the challenger disaster to evaluate systemic reasons leading to failure in team decision making. Additionally, the MakerSpace is used to foster creative problem solving, collaboration skills, and knowledge of technologies that may shape their professions' future.
\end{abstract}

The instructor's' role in the course is to serve as facilitators and guides while students work to develop their solutions. This process ensures that students take ownership of their project as an engaged team. It allows students to strengthen their problem-solving and collaboration skills. The interdisciplinary teaching team models the teamwork skills the students are learning. The aim is to promote interdisciplinary learning, foster teamwork, and improve student engagement. Other course objectives are to develop students' creative problem solving, empathetic design practices, communication skills, prototyping skills, and ethical reasoning. Students are expected to become proficient at the empathetic design process as well as interdisciplinary communication and teamwork. Creative problem solving, ethical reasoning, and realization of a product through prototyping are expected to be emergent skills that will need further refinement after the course.

Research was conducted with consenting participants from the course using qualitative content analysis of student responses to prompts with the aim of assessing course outcomes. Results indicate that the multidisciplinary experience and use of and maker technologies enhance student learning and engagement, foster teamwork and interdisciplinary skills, and increase students' ability to innovate.

\section{Introduction}

It is well known that engineering involves integrating broad knowledge towards some purpose, generally to address a need or solve a problem. As we move into a global future, engineers can no longer isolate themselves and must be prepared to work across disciplinary, cultural, political, and economic boundaries. Every day, engineers are confronted with complex challenges that range from personal to municipal to national needs. ${ }^{1}$ The ability for future engineers to work in multidisciplinary, interdisciplinary, and transdisciplinary environments will be an essential competency. ${ }^{2}$ Furthermore, with greater emphasis being placed on understanding social, economic and environmental impacts of engineered solutions, another essential competency is the cognitive flexibility to think about the whole system at different levels of fidelity and in different time scales. ${ }^{3,4}$ Undergraduate education must train students to not only solve engineering challenges that transcend disciplinary boundaries, but also communicate, transfer 
knowledge, and collaborate across technical and non-technical boundaries. The same can be said for healthcare professionals.

Many of today's STEM students will be tomorrow's healthcare professionals responsible for solving an increasing number of problems that are wide in scope. Current medical issues are both critical and complex enough such that no discipline will be able to solve them alone; there will need to be interdisciplinary teams working together to solve the technical and non-technical aspects of future problems. The World Health Organization characterizes interprofessional education (IPE) as "essential" and occurring when students from at least two professions learn "about, from, and with each other" toward the result of improving health outcomes for patients, families, or communities. ${ }^{5}$ The term "interprofessional" tends to be used in health and educational sectors, while the term "interdisciplinary" is used elsewhere. Because there are a mix of health professions and other disciplines in the course we use the terms interchangeably with knowledge that there are some differences.

One approach to appropriately training these future problem solvers is to create interdisciplinary educational experiences for undergraduate students that immerse them into authentic experiences. The broad goal of the developed interdisciplinary course is to allow preprofessional biology, pre-nursing, and engineering students to leverage MakerSpace technology to produce and communicate tangible solutions to current challenges in community health. For the past two course offerings students developed solutions to metabolic syndrome using MakerSpace technologies (i.e., 3D printing, laser cutters/engravers, virtual reality, and related software) as part of the course project. Communication between disciplines that impacts each other but may have different biases and goals is important, and is facilitated through teamwork. In the course, students receive explicit training in problem solving techniques, teamwork, and communication. For example, students form their teams using the StrengthsFinders analysis to build on the individual strengths present in the group, and the teams watch a video on the challenger disaster to evaluate systemic reasons leading to failure in team decision making. Additionally, the MakerSpace is used to foster creative problem solving, collaboration skills, and knowledge of technologies that may shape their professions' future.

By modeling the course project interdisciplinary team structure with an interdisciplinary teaching team, the aim is to promote interdisciplinary learning, foster teamwork among the student teams, and improve student engagement. Other course objectives are to develop students' creative problem solving skills, empathetic design practices, interdisciplinary communication skills, prototyping skills, and ethical reasoning. Students are expected to become proficient at the empathetic design process as well as interdisciplinary communication. Creative problem solving, ethical reasoning, and realization of a product through prototyping are expected to be emergent skills that will need further refinement after the course.

The paper is organized as follows: the background section reviews relevant literature on interdisciplinary experiences between engineering, nursing, and biology. The course structure section gives an overview of how the course is composed, while the implementation section describes in detail how the course is taught. A section on student outcomes discusses student learning gains as a result of taking the course. The paper closes with sections on lessons learned from teaching the course, and conclusions and future work. 


\section{Background}

\section{National Calls and Reports}

In 2008, National Academy of Engineering (NAE) unveiled 14 "Grand Challenges for Engineering", the result of a study commissioned by the National Science Foundation to guide policy and budget decisions and inspire a new generation. ${ }^{6}$ At the news conference of the release, Dr. Charles Vest (President of NAE) mentioned the anticipated synergy ("interdependence") that will exist between engineering, science, and medicine in solving the problems of the $21 \mathrm{st}$ century. Several of the challenges relate in some way to the quality of human health, particularly the "Engineer Better Medicines" challenge, including development of new drugs and clinical diagnostics.

In 2010, the Institute of Medicine in The Future of Nursing: Leading Change, Advancing Health report emphasized the importance of standardization and innovation. ${ }^{7}$ Hospitals that have or are seeking magnet status are changing the role of nurses to include evidence-based practice in areas such as communicating observations and on the job problem solving. ${ }^{8}$ Magnet status ensures high quality care and innovations in professional nursing practice. Furthermore, there is a move towards allowing nurses the autonomy to deliver care to the full scope of practice. ${ }^{9,10}$ In the hightech medical practice environment, nurses must be adaptive and flexible in using knowledge to increase patient safety and to positively impact health outcomes.

\section{Interdisciplinary Education}

Opportunities currently exist for professionals to develop problem solving, collaboration, and innovation skills. However, there are many fewer opportunities for undergraduate students to cultivate these skills before they are deeply embedded in their profession specific courses. ${ }^{11,12}$ Educating pre-professional students in processes of creativity and innovation is recognized and encouraged to enhance innovation in addressing current health challenges. ${ }^{13}$ Studies documenting the importance of Interprofessional Education (IPE) for medical and nursing students have identified successful outcomes including improved communication skills, increased knowledge of role, and greater self-efficacy. ${ }^{14,15}$ Moreover, IPE has been shown to positively change students attitude towards working in teams for medical students. ${ }^{16}$ These outcomes are process-oriented; yet, two separate systematic literature reviews have determined that for healthcare professionals, team process improvements such as strong communication and team monitoring behaviors can positively affect patient outcomes. ${ }^{17,18}$ Significantly, Winters found that objectives in the engineering curriculum aligned well with the objectives in the nursing curriculum such as to facilitate IPE. ${ }^{19}$ Given this evidence we believe that the benefits of IPE extend not only to pre-nursing and pre-professional health students but to engineering students as well.

While educating nursing and medical students together is important, we suggest that other options for teaching some of the paramount competencies to diverse groups are needed. The problem solving and communication skills required for healthcare professionals to successfully work together are skills that will benefit other professionals such as engineers. Collaborative education between engineering and medical students has shown to result in innovation for 
community benefit through assistive device creation ${ }^{11}$, addressing real-world clinical problems $^{12,20,21}$, and improvements to medical teaching laboratories ${ }^{22}$.

Interdisciplinary collaboration between engineering, nursing, and the sciences at the undergraduate level primarily occurs during capstone, or the final year of engineering study. For example, the Interdisciplinary Medical Product Development (IMPD) senior design capstone course at the University of Illinois at Chicago involves students and faculty from bioengineering, medicine, industrial design, marketing, and graphic design. ${ }^{20}$ At California Baptist University, engineering capstone students design devices to assist hearing impaired individuals and work with nursing students to prepare the units for clinical testing. ${ }^{23}$ A cross institution collaboration between biomedical engineering students at Lawrence Technological University and mechanical engineering and nursing students from University of Detroit, Mercy has resulted in multidisciplinary capstone teams focused on helping patients from a local Veteran Administration hospital with physical disabilities. ${ }^{24}$ In all three cases, a human-centered design approach was taken.

Opportunities to engage in interdisciplinary projects outside capstone are rare. Two examples from literature include the global health course at Western New England University ${ }^{25}$ and the Clinical Immersion at Disciplinary Interfaces at Tennessee Technological University ${ }^{21}$. Both courses bring together undergraduate engineering and science students and immerse them in a healthcare environment. Survey data for the global health course indicated increased studentreported confidence in an ability to develop solutions to global health issues, and answers openended questions revealed impacts at the academic, professional, and/or personal levels. ${ }^{25} \mathrm{~A}$ critical thinking assessment test showed that students in the Clinical Immersion at Disciplinary Interfaces course had a statistically significant increase $(\sim 25 \%)$ in overall critical thinking. ${ }^{21}$ Both courses resulted in significant growth and learning for students, which is motivating for the development of interdisciplinary courses.

The ability for future engineers to work in interdisciplinary environments will continue to be an essential competency. Undergraduate education must train students to not only solve challenges that transcend disciplinary boundaries, but also to communicate, transfer knowledge, and collaborate across technical, non-technical, physical, virtual, and discipline-specific linguistic boundaries. Interdisciplinary courses are one approach to meeting this need.

\section{Course Structure}

The Interprofessional Innovations course at James Madison University is open to sophomore through senior-level engineering, nursing, and biology students and is co-taught by a faculty member from these disciplines who are actively involved in each weekly class session. The weekly 3-hour class sessions are taught as a "laboratory" experience with students mainly involved in active learning of fundamental principles for effective interdisciplinary collaboration. Students work in mixed teams toward a tangible solution to a community health challenge as part of the course project for the duration of the semester. The class is taught in a MakerSpace; a novel instructional space developed according to constructivist learning principles ${ }^{26}$ in which participants co-learn and co-create ${ }^{27}$. The MakerSpace is an essential element of the course, as it facilitates students' problem solving through prototyping and testing a solution with frequent 
iterations. Students used MakerSpace tools such as a 3D printer and laser cutter to fabricate multiple ideas simultaneously. A large format printer allowed students to make product posters that helped to refine the target audience and better articulate their solution. Students are required to read four texts in the following order: Strengths Based leadership: Great Leaders, Teams, and Why People Follow ${ }^{28}$, Creative Confidence ${ }^{29}$. Fabricated $^{30}$, and The Immortal Life of Henrietta Lacks $^{31}$. The Strengths Based Leadership book is completed for the first week of class along with the StrengthsFinder 2.0 assessment. The other three books are divided into a series of chapters to be read weekly. Students journal weekly to deepen their understanding of course concepts as well as to allow faculty to provide feedback on their growth. In addition to reflective writing, students sketched in their journals. Sketches could be ideas for their project or as responses to the weekly questions. In addition to encouraging reflective growth, these activities were designed to help students become comfortable with the basic skills, like sketching, required to implement design thinking. Notably, some student disciplines were relatively unfamiliar with narrative reflection while others rarely sketch as part of their work.

The first iteration of the course was offered as a special topics course in each discipline and cross listed through Interprofessional Education at James Madison University. Biology and health science students did not leverage this designation and the cross listing was dropped in the second iteration. Each instructor oversaw their respective listing of the course, and the recruitment of students. The instructor from each discipline either recruits or opens enrollment to eight students for the course for a maximum number of 24 students. The biology instructor recruited students based on past interactions; the students tended to be hard workers and creative thinkers. The nursing instructor recruited students from the chronic illness minor. The engineering instructor recruited students that had interest in medical applications in engineering or were comfortable with ambiguity.

\section{Implementation}

The implementation of the course is the shared responsibility of the instructors and the students. The course is rooted in the social constructivist theory of learning ${ }^{32,33,34}$ and adopts a learnercentered strategy ${ }^{35,36}$. Generally, a learner centered strategy puts the work of learning on the students and the work of designing effective learning environments on the instructors. Students reflect on what they are learning and have some control over the learning environment and process. Instructors facilitate collaborative relationships within the course and explicitly teach strategies important to the course such as problem solving, how to think, how to learn, and how to communicate. The pedagogies adopted are based explicitly on the course learning outcomes listed in Table 1. The instructional framework is based on the Kolb learning cycle: concrete experience leads to reflective observation leads to abstract conceptualization leads to active experimentation leads back to the concrete experience. ${ }^{37}$ Design thinking is mapped to the Kolb learning cycle as a problem solving methodology in order to gain inspiration (concrete experience and reflective observation), generate ideas (abstract conceptualization), and then implement (active experimentation) those ideas in successive iterations (concrete experience) as demonstrated in Table 2. A project-based learning pedagogy is used to incorporate the elements of key knowledge, a challenging problem or question, sustained inquiry, authenticity, student voice and choice, reflection, critique and revision, and public product. ${ }^{38}$ Students work in permanent teams throughout the semester and are given instruction on Tuckman's stages of team 
formation $^{39,40}$ : forming, norming, storming, performing, adjourning and avoiding group think.

Table 1. Course learning outcomes.

1. Apply problem solving skills to an actual community health challenge for vulnerable populations

2. Use collaboration skills to work together with a group of diverse pre-professionals

3. Engage in self analysis to identify systemic factors relevant to supporting quality team work

4. Evaluate personal strengths and their applications to leadership and participation in professional teams

5. Discuss the ethical, legal, and practical implications of applying novel technologies, particularly for use with vulnerable populations

6. Produce and communicate a tangible product using MakerSpace technology that has the potential to improve a community health challenge

7. Evaluate feasibility, potential impact, and limitations of potential solutions

Table 2. Course activities aligned with the Kolb learning cycle.

\begin{tabular}{|l|l|}
\hline $\begin{array}{l}\text { Concrete } \\
\text { experience }\end{array}$ & $\begin{array}{l}\text { Students use empathy to understand the challenges for members of the } \\
\text { community with a chronic illness such as metabolic syndrome. They } \\
\text { interact consistently and frequently with members of the patient } \\
\text { community throughout the experience. They get feedback from the } \\
\text { patient community on their developing solutions. }\end{array}$ \\
\hline $\begin{array}{l}\text { Reflective } \\
\text { observation }\end{array}$ & $\begin{array}{l}\text { Students participate in weekly reflective journaling individually and in } \\
\text { guided group discussions where they respond to prompts about their } \\
\text { process and their developing solutions. The course culminates in an oral } \\
\text { final where students reflect on the concepts required to maintain a } \\
\text { creative design process and produce a quality product in the course. }\end{array}$ \\
\hline $\begin{array}{l}\text { Abstract } \\
\text { conceptualization }\end{array}$ & $\begin{array}{l}\text { Students learn in ways that are different from their typical experience. } \\
\text { Engineering students often comment on how much they enjoyed the } \\
\text { opportunity to work with people from outside their major and share their } \\
\text { knowledge of the design process. Nursing students often comment on } \\
\text { their ability to work with technologies and contribute to the design } \\
\text { process. Biology students often comment on increasing their creativity } \\
\text { and learning processes for problem solving. }\end{array}$ \\
\hline $\begin{array}{l}\text { Active } \\
\text { experimentation }\end{array}$ & $\begin{array}{l}\text { useful feedback from community members. They begin with basic } \\
\text { prototypes and iteratively make changes based on feedback from the } \\
\text { patient community. They culminate by presenting a beta prototype to } \\
\text { stakeholders. }\end{array}$ \\
\hline
\end{tabular}


The instructors model a team-based collaborative approach for students to adopt in the course. The students and instructors complete the StrengthFinders 2.0 self-assessment to identify the individual suite of strengths. In the first course meeting, faculty explain how their diversity in strengths positively impacts both their own experience and the students'. Students bring their StrengthFinder 2.0 self-assessment printout and participate in a "speed dating" type activity in which they present their strengths to other participants in the class. The focus of the activity is on building a team that has strengths in all areas. After submitting their teammate choices, students are assigned to teams by the faculty based on a combination of discipline, student preferences, and needs of the entire group. All teams have one or two students from each discipline for a total of four teams.

The instructors and students take four weeks to read Creative Confidence, which provides an accessible example of an empathy-based design process. The text has examples to which students and faculty can relate and makes the case that creativity is not innate, but is a learned skill. This point is particularly important for students in STEM and STEM-related fields. Students are asked to reflect directly on the reading in two of their weekly journal entries. In the second week of the course, students and instructors engage in a design challenge suggested in the text, the Wallet Project ${ }^{41}$, to practice this mode of thinking, and set the tone for the rest of the course (Figure 1).
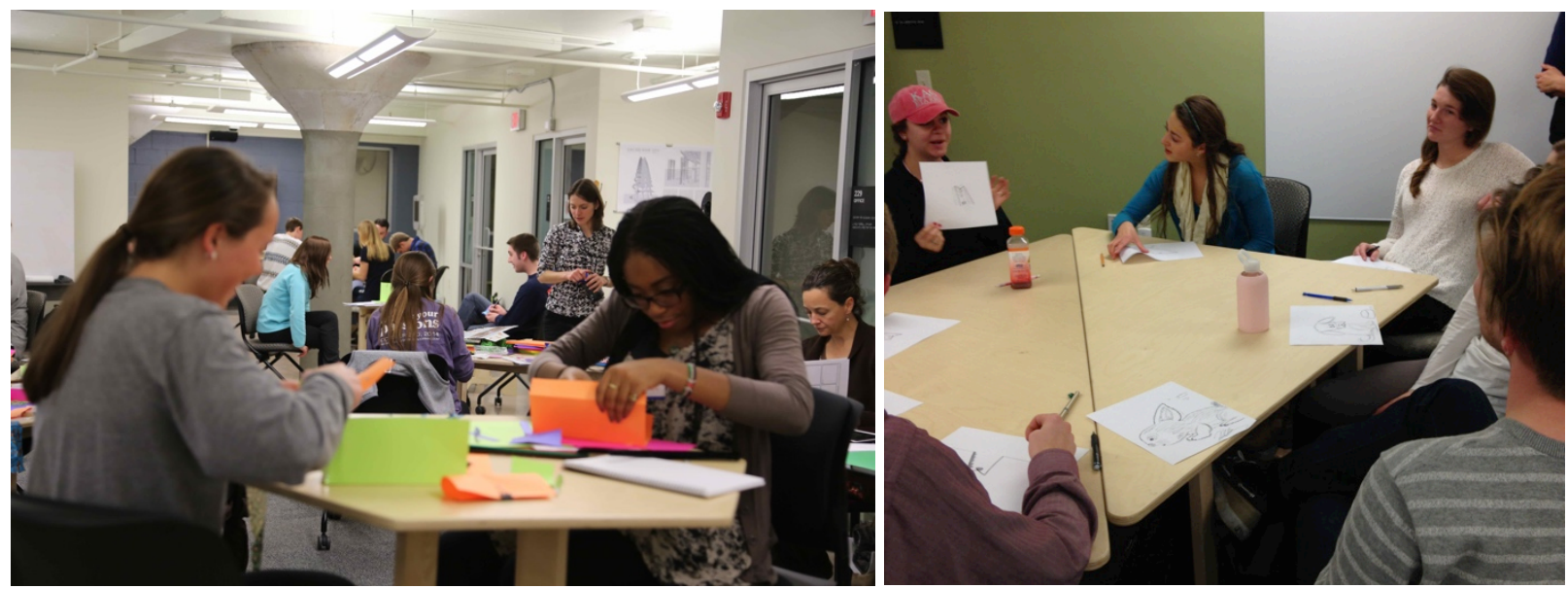

Figure 1. Students engaged in the wallet project (left) and individual creativity exercise (right)

The instructors and students read and reflect on the text Fabricated as inspiration for their use of the MakerSpace prototyping tools. Students are asked to read several chapters per week for five weeks. There are brief in-class discussions of the text and students reflect on how the reading applies to their process and their product in two of their weekly journal entries. As students are reading the text they were also learning to use the MakerSpace tools through tutorials. Students are required to practice fabrication in out-of-class lab times. Teams are required to have some digitally manufactured element to their final solution, which could be during iterative prototyping leading to the final product or in the final product itself. This is left to the teams' discretion.

The instructors and students read the text The Immortal Life of Henrietta Lacks to elucidate the ethical considerations of innovation, especially regarding vulnerable populations. During the four 
weeks allotted to reading the text, there were in-class discussions of the implications as well as a lecture and discussion devoted to James Madison University's 8 Key Questions. ${ }^{42}$ Students were asked to reflect on the elements that "surprised" them and the themes they observed in the Henrietta Lacks text and how those themes relate to their work in the course in two of their weekly journal entries.

The course uses project-based learning to frame the activities. The student teams work on the authentic and challenging problem of a chronic illness affecting the local community; specifically, metabolic syndrome. Metabolic syndrome is a suite of factors that increase the risk of heart disease, diabetes, and stroke. ${ }^{43}$ Students identify a subset of the community to focus on (e.g., college students, office workers, elementary children) and then gain empathy for members of that sub-community by interviewing and observing them. The information is distilled and synthesized using empathy maps. Students reflect on their findings and use the insights in collaborative ideation sessions. Teams then work toward developing a tangible solution based on the specific challenges of their identified population. Feedback from members of the community is provided at key points in the semester to facilitate the process of prototype iteration. Students present their product to the community in a final presentation.

Multiple invited guest lecturers speak about topics that are related to the process of innovation and enrich the student learning during the course. Guest lecturers include a healthy heart program coordinator from a local hospital, a faculty member whose research intersects with metabolic syndrome, a venture capital expert, the Director of James Madison University's Technology Innovation, and the Director of James Madison University's Center for Entrepreneurship. The purpose of these speakers is to broaden the scope for solution finding and provide perspective on the process of innovation for students that may not have experience in these areas.

The "typical" class varies in structure from the beginning of the semester to the end of the semester. Every class meeting, however, starts with a creativity exercise (Figure 1) to prime students for the day's activities. An overview of the course topics and weekly structure is given in Table 3. Early in the semester, students may hear a mini-lecture that introduces important content and skills, including how to conduct literature searches, how to conduct interviews, the process of team formation, the biology of metabolic syndrome, and steps in the design process. These mini-lectures are followed by in-class project work time. There are whole class discussions in multiple classes toward mid-semester focused on the ethics of developing new technologies, and based on their reading of the Henrietta Lacks text that illustrates the ethical tension between advancing technology and unintended consequences, particularly for vulnerable members of society. 
Table 3. Course outline.

\begin{tabular}{|c|c|c|}
\hline & In-Class Activities & Assignments \\
\hline Pre-class & & 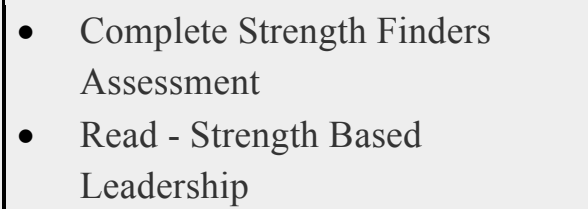 \\
\hline Week 1 & $\begin{array}{l}\text { - } \text { Course Introduction } \\
\text { - Speed Dating Activity } \\
\text { - Team Theory } \\
\text { - Individual Research on Metabolic Syndrome }\end{array}$ & $\begin{array}{l}\text { - Assignment - List two peers from } \\
\text { other disciplines whose strengths } \\
\text { compliments yours, and why. } \\
\text { - Reading - Metabolic syndrome } \\
\text { - Journal }\end{array}$ \\
\hline Week 2 & $\begin{array}{ll}\text { - } & \text { Creativity Exercise } \\
\text { - } & \text { Wallet Project } \\
\text { - } & \text { Metabolic Syndrome Lecture } \\
\text { - } & \text { Team Building Activity }\end{array}$ & $\begin{array}{l}\text { - Reading - Creative Confidence } \\
\text { - } \text { Grade percentages } \\
\text { - Journal }\end{array}$ \\
\hline Week 3 & $\begin{array}{l}\text { - } \quad \text { Creativity Exercise } \\
\text { - } \quad \text { Metabolic Syndrome Guest Lecture } \\
\text { - } \quad \text { Team Building Activity }\end{array}$ & $\begin{array}{l}\text { - Reading - Creative Confidence } \\
\text { - Journal }\end{array}$ \\
\hline Week 4 & $\begin{array}{l}\text { - } \quad \text { Creativity Exercise } \\
\text { - Empathy Mapping Exercise } \\
\text { - } \quad \text { Team Building Activity }\end{array}$ & $\begin{array}{l}\text { - Reading - Creative Confidence } \\
\text { - Journal }\end{array}$ \\
\hline Week 5 & $\begin{array}{ll}\text { - } & \text { Creativity exercise } \\
\text { - } & \text { Ideation Lecture } \\
\text { - } & \text { Introduction to MakerSpace Tools - 3D } \\
\text { printing } \\
\text { - Team Building Activity }\end{array}$ & $\begin{array}{l}\text { - Reading - Creative Confidence } \\
\text { - Journal }\end{array}$ \\
\hline Week 6 & $\begin{array}{l}\text { - } \text { Creativity Exercise } \\
\text { - Introduction to all other MakerSpace Tools } \\
\text { - Team Building Activity }\end{array}$ & $\begin{array}{l}\text { - Reading - Fabricated } \\
\text { - Journal }\end{array}$ \\
\hline Week 7 & $\begin{array}{ll}\text { - } & \text { Creativity Exercise } \\
\text { - } & \text { Project Work Time } \\
\text { - } & \text { Team Building Activity }\end{array}$ & $\begin{array}{l}\text { - Reading - Fabricated } \\
\text { - Journal }\end{array}$ \\
\hline Week 8 & $\begin{array}{l}\text { - } \quad \text { Creativity Exercise } \\
\text { - } \quad \text { Project Work Time } \\
\text { - } \quad \text { Team Building Activity }\end{array}$ & $\begin{array}{l}\text { - Reading - Fabricated } \\
\text { - Journal }\end{array}$ \\
\hline Week 9 & \multicolumn{2}{|c|}{ Spring Break } \\
\hline
\end{tabular}




\begin{tabular}{|c|c|c|}
\hline Week 10 & $\begin{array}{ll}\text { - } & \text { Creativity Exercise } \\
\text { - } & \text { Venture Capitalist Guest Lecture } \\
\text { - } & \text { Team Building Activity }\end{array}$ & $\begin{array}{l}\text { - } \text { Reading - Fabricated } \\
\text { - Journal }\end{array}$ \\
\hline Week 11 & $\begin{array}{l}\text { - } \text { Present Alpha Prototype to Class } \\
\text { - } \text { Project Work Time } \\
\text { - } \quad \text { Team Building Activity }\end{array}$ & $\begin{array}{ll}\text { - } & \text { Reading - Fabricated } \\
\text { - } & \text { Journal } \\
\text { - } & \text { Incorporate Feedback into Project }\end{array}$ \\
\hline Week 12 & $\begin{array}{ll}\text { - } & \text { Creativity Exercise } \\
\text { - } & \text { Ethics Lecture } \\
\text { - } & \text { Team Building Activity }\end{array}$ & $\begin{array}{l}\text { - } \text { Reading - Henrietta Lacks } \\
\text { - Journal }\end{array}$ \\
\hline Week 13 & $\begin{array}{l}\text { - } \text { Creativity Exercise } \\
\text { - Intellectual Property Guest Lecture } \\
\text { - } \\
\text { - } \\
\text { Project Work Time } \\
\text { Tuilding Activity }\end{array}$ & $\begin{array}{l}\text { - Reading - Henrietta Lacks } \\
\text { - Journal }\end{array}$ \\
\hline Week 14 & $\begin{array}{ll}\text { - } & \text { Creativity Exercise } \\
\text { - } & \text { Entrepreneurship Guest Lecture } \\
\text { - } & \text { Team Building Activity }\end{array}$ & $\begin{array}{l}\text { - } \text { Reading - Henrietta Lacks } \\
\text { - Journal }\end{array}$ \\
\hline Week 15 & $\begin{array}{l}\text { - Present Beta Prototype to Class } \\
\text { - } \text { Project Work Time } \\
\text { - } \text { Team Building Activity }\end{array}$ & $\begin{array}{ll}\text { - } & \text { Reading - Henrietta Lacks } \\
\text { - } & \text { Journal } \\
\text { - } & \text { Incorporate Feedback into Project }\end{array}$ \\
\hline Week 16 & - Community Assessment & $\begin{array}{ll}\text { - } & \text { Journal } \\
\text { - Incorporate Feedback into Project }\end{array}$ \\
\hline Week 17 & - Oral final & \\
\hline
\end{tabular}

The students use a physical journal to record responses to weekly prompts, and as an inspiration or ideation record. Students upload digital images of their physical journal to Evernote $\mathbb{R}$ and all instructors share the grading responsibilities for all students. Toward the end of the semester, students have more class periods to work on their course project in which instructors work closely with the teams on their prototypes. Work days are offered as a way for students to use the MakerSpace technology to prototype, work with instructors as consultants, and engage in the iterative process of product development. These times are particularly useful for student growth as they promote student autonomy. Students are responsible for defining their next steps, taking action, and evaluating results. During this process, instructors are guiding students and providing feedback; the process is considered more important than the actual prototype. Students submit an alpha prototype mid-semester and a beta prototype for the community assessment at the end of the semester. Every class ends with a team building challenge in which students strategize and experiment with ways to solve a given problem as fast as possible within the constraints (Figure 2). 
There are several assignment types used throughout the semester that are aligned with achieving the course objectives while meeting project-based learning standards and following the Kolb learning cycle. Individually, students respond to a weekly prompt by writing or sketching in a physical journal. As a team, they work on a project. The project is assessed primarily for progress on the design process, rather than the final product. The process is assessed by a final presentation at the community showcase (discussed below). Students complete an oral final at course end. The set of 5 exam questions are provided one week in advance and each student is given 10 minutes to answer two randomly selected questions without notes. All three faculty assess each student and grade on the clarity of response. Team members evaluate each other's performance in a peer evaluation at the end of the semester.

Community members are invited to a showcase to celebrate and assess the projects at the end of the semester. Invited guests include doctors, nurses, and staff from both the local hospital that work in the area of metabolic syndrome and from the community health center, guest speakers for the course, Academic Unit Heads, each of the Deans from colleges represented in the course, and the Provost. The students invite their family and friends. The event is catered and attendees eat and visit each team's product station. Teams prepare promotional materials for the event including posters and pamphlets. They also display their solution prototype (Figure 2). Following the social time, each team gives an 8-minute pitch followed by a question and answer period. A rubric is provided for the attendees of the community assessment that focuses on the quality of the presentation and viability of the potential solution (Table 4). Attendees are encouraged to vote for a "People's Choice Award". Table 5 provides an overview of the student projects from the first two offerings of the course.
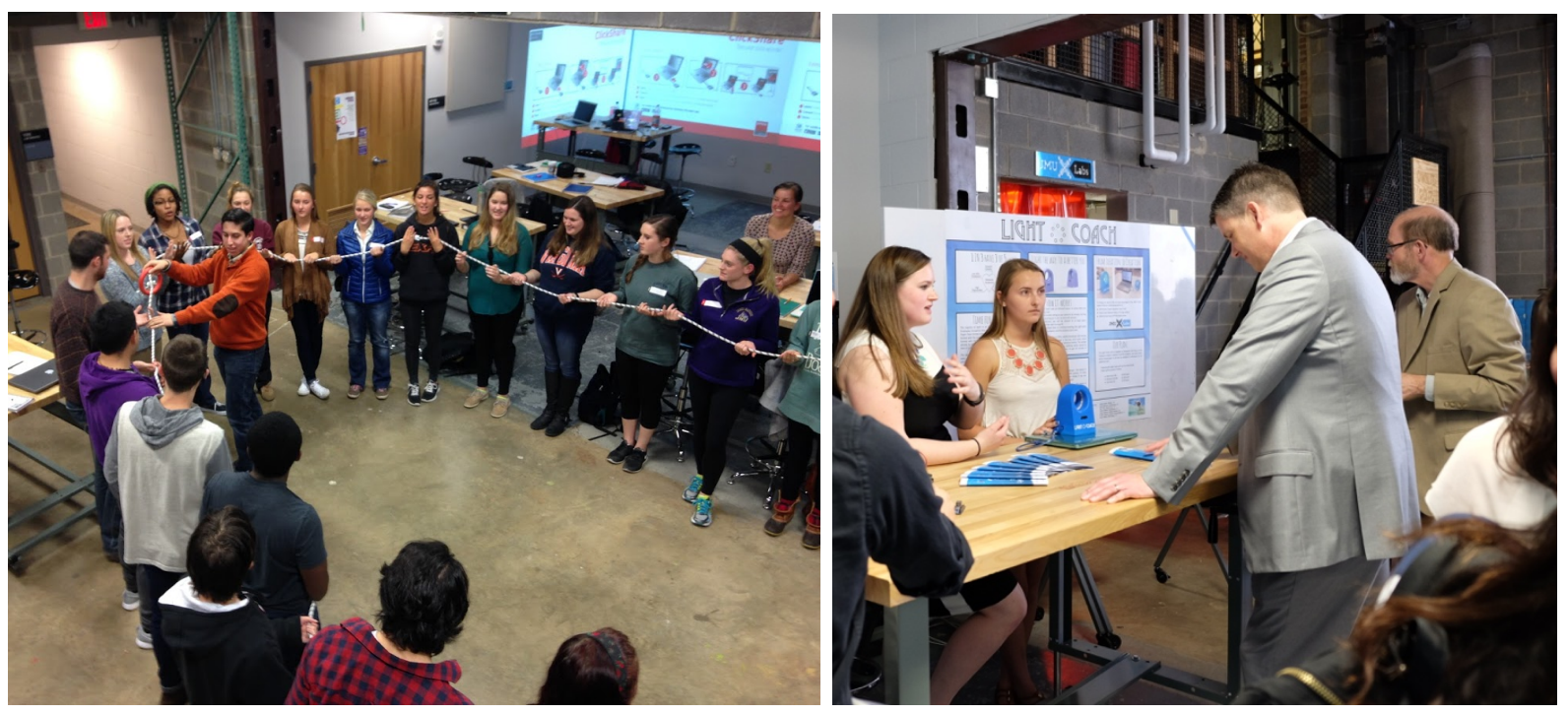

Figure 2. Students engaged in a whole class team building challenge (left) and community showcase (right) 
Table 4: Community Assessment Rubric.

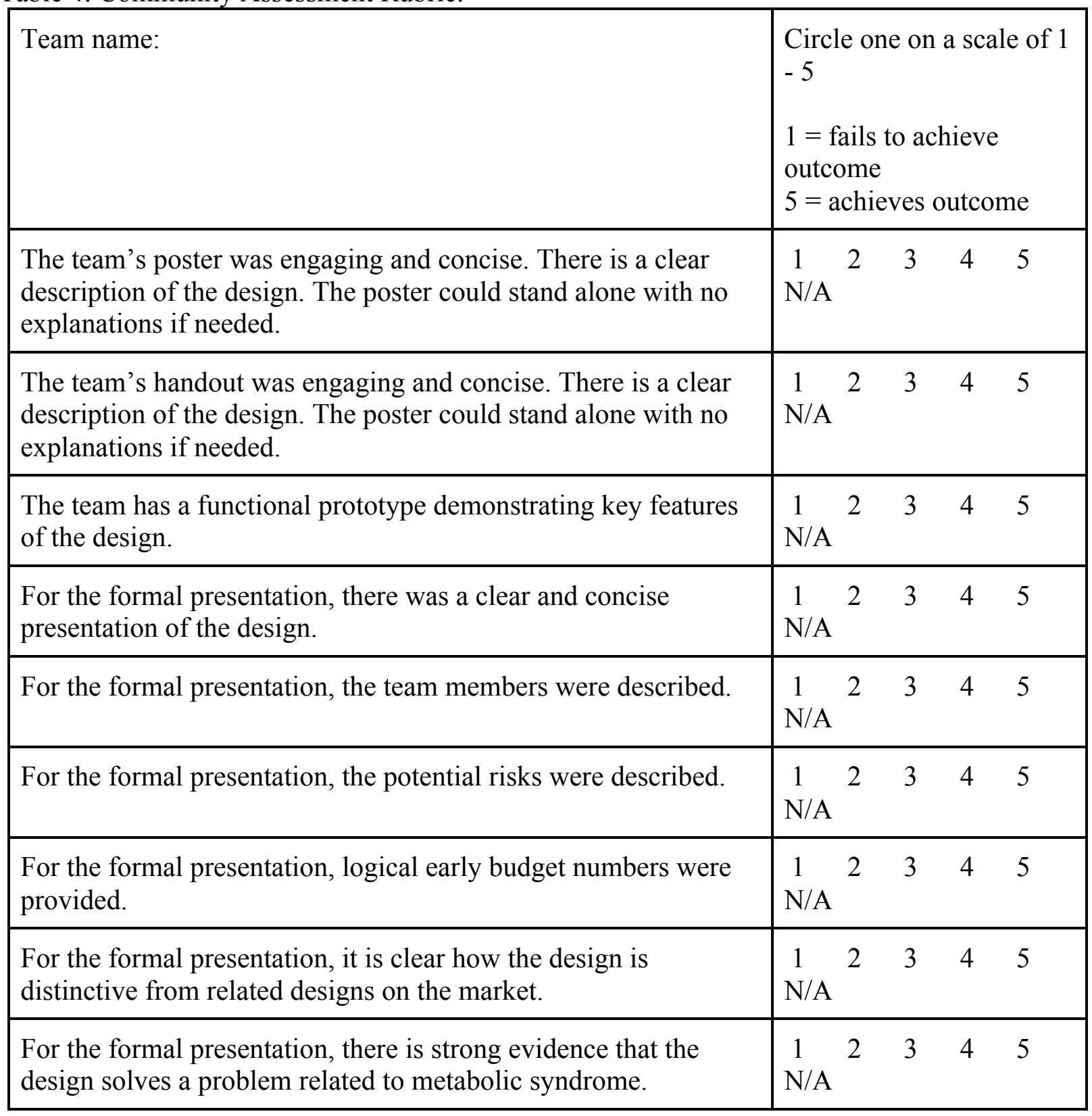

The student projects varied in scale and scope across the two iterations of the course. Some teams focused on early prevention of metabolic syndrome through awareness or educational approaches, while others focused on development of personal tools that can assist with overcoming the risk factors. A few teams considered multiple age groups and targeted families with their designs. Although suggested, no teams focused on assisting healthcare professionals with diagnosis of metabolic syndrome. 
Table 5. Student project titles and descriptions from the two iterations of the course.

\begin{tabular}{|l|l|}
\hline \multicolumn{1}{|c|}{ Project Title } & \multicolumn{1}{c|}{ Abbreviated Description } \\
\hline MetaNutrition & $\begin{array}{l}\text { An app. Users enter risk factors and then barcode scan grocery store } \\
\text { items. The program matches the food content to the person's specific risk } \\
\text { factors and provides risk specific nutritional guidance. }\end{array}$ \\
\hline Food Frenzy & $\begin{array}{l}\text { A life-size board game aimed at teaching school age children healthy } \\
\text { behaviors while getting them active in the moment. Packaging designed } \\
\text { for ease of distribution. }\end{array}$ \\
\hline Octospec & $\begin{array}{l}\text { A smartphone attachment that scans the metabolic content of prepared } \\
\text { food and displays the information on the smartphone. }\end{array}$ \\
\hline Level-up & $\begin{array}{l}\text { An awareness campaign for coordinating "ice-bucket challenge" type } \\
\text { activities related to Metabolic Syndrome. }\end{array}$ \\
\hline Family Fit and Fun \\
Center & $\begin{array}{l}\text { An indoor playground with equipment designed for adults and children to } \\
\text { play on simultaneously. }\end{array}$ \\
\hline The Light Coach & $\begin{array}{l}\text { A small light designed to target sedentary adult workers. A sensor in the } \\
\text { device detected movement and alerted when movement was needed. }\end{array}$ \\
\hline The Pedal Pusher & $\begin{array}{l}\text { A lightweight machine that could be used to exercise while sitting down. } \\
\text { Designed to fit under a desk. Motion charged a cell phone in order to } \\
\text { promote use. }\end{array}$ \\
\hline Chair Pair & $\begin{array}{l}\text { A scale designed to fit into a chair cushion. Automatically measured } \\
\text { weight and sent it to a tracking app to promote healthy habits for the } \\
\text { whole family. }\end{array}$ \\
\hline
\end{tabular}

\section{Student Outcomes}

The learning outcomes of the course are given in Table 1. Assessment of student learning gains against the course learning outcomes was achieved through course and research methods as described in the following sections.

\section{Course measures of student learning outcomes}

Student progress toward course outcomes was evaluated using both formative and summative methods. Students had a series of relatively short formative exercises that were awarded points for participation. These assignments fall into thematic categories of practicing skills (e.g. Start a TinkerCad account and do the first tutorial, Create a Diigo account, Avoiding groupthink), learning about professional behavior (e.g., Find and follow an innovation expert on social media), or notes on the team's process (e.g., Upload photos of your empathy map, draft of problem statement, draft of alpha prototype presentation). Summative assessments were more structured in their evaluation. Students were assessed on the quality of their weekly journal entries. Each instructor was responsible for grading a subset of students that was different from week to week. Students were also required to assess peers at the end of the semester in a written document. The summative assessment of the project is scaffolded into six benchmarks throughout the semester (first draft of prototype, timeline, documentation of open lab time, draft of final presentation, actual final presentation, and final product). The final summative assessment is an oral final exam.

At course end each student is individually given an oral final by all course faculty. The student answers two randomly selected questions aimed to illustrate their understanding of the concepts required to maintain a quality process for the course (Course learning outcomes: 3,4,5,7). 
Students have several minutes to answer each question without notes. For example, students have been asked to list their strengths as measured by the StrengthFinders assessment, and to provide specific examples of ways their strengths contributed to team constructive and destructive behaviors throughout the course. Another example question asked students to discuss the ethical, legal (intellectual property), and practical implications of applying novel technologies, particularly for use with vulnerable populations. Students also produce a tangible product and visual support materials (posters, handouts), and use the product and materials in a community presentation to stakeholders (Course learning outcomes: 1,2,6,7).

Table 6 gives some numerical data regarding student learning for both iterations of the course. Not all course assessments are included, but multiple assessments are included for each course learning outcome. The center column gives the desired level of attainment for each assessment. For example, the instructors desired that students get a grade of $90 \%$ or higher for the draft problem statement assignment. Because the assessments are graded primarily for process and/or completion, the desired level of attainment for most assessments was an A. The data show that in the second iteration of the course, students performed higher on all oral final exam questions, the peer evaluation, and the course project. Students in the second iteration also improved in their ethical reasoning ability.

Table 6. Objective assessment data for course measures of student learning.

\begin{tabular}{|l|c|c|c|c|}
\hline Assessment & $\begin{array}{l}\text { Course } \\
\text { Learning } \\
\text { Outcome(s) } \\
\text { Met }\end{array}$ & $\begin{array}{l}\text { Desired } \\
\text { Level of } \\
\text { Attainment }\end{array}$ & $\begin{array}{l}\text { Percent } \\
\text { Attainment } \\
- \text { 1st } \\
\text { Iteration }\end{array}$ & $\begin{array}{l}\text { Percent } \\
\text { Attainment } \\
\text { - 2nd } \\
\text { Iteration }\end{array}$ \\
\hline Draft Problem Statement & 1 & $90 \%$ & $100 \%$ & $100 \%$ \\
\hline Empathy Map & 1 & $90 \%$ & $100 \%$ & $100 \%$ \\
\hline Sketching/3D printing Journal Entry & 6 & $90 \%$ & $91 \%$ & $72 \%$ \\
\hline $\begin{array}{l}\text { Fabrication/Prototyping Journal } \\
\text { Entry }\end{array}$ & 6 & $90 \%$ & $91 \%$ & $80 \%$ \\
\hline Ethics Journal Entry & 5 & $90 \%$ & $86 \%$ & $88 \%$ \\
\hline Avoiding Group Think Exercise & 3 & $90 \%$ & $100 \%$ & $76 \%$ \\
\hline $\begin{array}{l}\text { Final Exam Question: Discuss the } \\
\text { ethical, legal (intellectual property), } \\
\text { and practical implications of } \\
\text { applying novel technologies, } \\
\text { particularly for use with vulnerable } \\
\text { populations }\end{array}$ & 5 & $70 \%$ & $33 \%$ & $60 \%$ \\
\hline $\begin{array}{l}\text { Final Exam Question: What is } \\
\text { metabolic syndrome? What are the } \\
\text { individual and community impacts } \\
\text { to life? What are the key elements } \\
\text { that require innovation to solve, and } \\
\text { why? }\end{array}$ & 7 & $70 \%$ & $80 \%$ & $82 \%$ \\
\hline $\begin{array}{l}\text { Final Exam Question: Describe the } \\
\text { innovation process as presented in } \\
\text { the course? What role does }\end{array}$ & 7 & $70 \%$ & & \\
\hline
\end{tabular}




\begin{tabular}{|c|c|c|c|c|}
\hline $\begin{array}{l}\text { prototyping in a MakerSpace have to } \\
\text { innovating solutions to problems in } \\
\text { general and specifically for } \\
\text { metabolic syndrome? }\end{array}$ & & & & \\
\hline $\begin{array}{l}\text { Final Exam Question: Describe how } \\
\text { your strengths (as measured in the } \\
\text { Strength Based Leadership) } \\
\text { contributed to team constructive } \\
\text { behaviors and also destructive } \\
\text { behaviors. Provide several specific } \\
\text { examples. }\end{array}$ & 3,4 & $70 \%$ & $67 \%$ & $70 \%$ \\
\hline $\begin{array}{l}\text { Final Exam Question: Find three } \\
\text { passages (one from each course text) } \\
\text { that are related to a course theme } \\
\text { that you choose. Tell us about the } \\
\text { theme, the texts, and describe the } \\
\text { relationship. }\end{array}$ & 7 & $70 \%$ & $71 \%$ & $75 \%$ \\
\hline Peer Evaluation & 2,4 & $90 \%$ & $73 \%$ & $84 \%$ \\
\hline Course Project Final Product & $1,2,6,7$ & $90 \%$ & $50 \%$ & $80 \%$ \\
\hline
\end{tabular}

\section{Research Measures of Student Learning Outcomes}

This course has been offered twice. In the first offering, narrative interviews were completed with Institutional Review Board approval at course end with consenting students. Consenting students were asked what they valued about what they learned from the class. The narratives resulted in over 250 unique and coded meaningful units. Six themes emerged from over 50 categories based on coded meaningful units. Of these themes four aligned directly with course learning outcomes. Two were unexpected. The themes are discussed below in order of the volume of supportive evidence. The findings of this research are described in detail elsewhere ${ }^{44}$.

The first theme, "learned teamwork skills" aligned with course learning outcomes. Students valued that they gained the skills required to work in a team. They learned to be open to the perspectives of others and understood that more could be accomplished as a team than as an individual. We explicitly tried to teach teamwork skills to students. We noticed this growth in all students, regardless of discipline. For example, one participant stated, "I think it was more important learning about the process of group work and what works and what doesn't."

The second theme, "learned to work in interprofessional teams" relates to the first theme but is unique in that students specifically valued the difference to work with other professions and the skills they developed to make that happen. They acknowledged that working with a group of interprofessionals led to a richer process and valued that. A participant stated 'I didn't have some of the skills that some of the engineers had, and I didn't have some of the skills some of the nurses had, they had a lot more people skills than I did to know how it affected people. And I really had to rely on that and I think this took me out of my comfort zone so I could do that."

Many students valued the growth that came from the course being challenging and oriented around actual problems, thus the third theme is "Valued growth from challenging problem 
solving". They appreciated that although working in the MakerSpace was initially uncomfortable it allowed for prototyping that facilitated problem solving. The student-centered approach to teaching the course was something students appreciated. A participant said, "Okay, I think I learned a lot about [things] that I never had before, like engineering especially. Just kind of the whole design process and thinking creatively. I don't think I've ever done that in any class before. And I also learned a lot about technology. I did not know 3D printing was actually a thing. And I think that it was really cool to be exposed to that. And also the virtual world was really cool. I don't know and I also never had a class that was so open and stuff."

We did not expect for students to integrate the course learning so fully as to be able to contextualize it within their broader educational development; yet, that occurred. Students "saw the course in the context of their past and future work". They recognized that the skills they learned would be useful as they moved into their professions. They were proud of their accomplishments in the course and mentioned that they often talked about the course to others. Some brought family members and peers to the final presentation to show off their work. A student stated, "But it's opened something that was closed off to me completely before so that was really interesting." Students "learned about their own profession". Although we recognized that understanding one's own role is part of developing an interprofessional identity we were unsure it could happen so early on in professional development. We noticed students' abilities, as the course progressed, to articulate the role of their chosen profession and even define their scope of practice as it related to the problem at hand. Students too noticed this, for example one student commented, "And I've learned about professionalism outside of me but I've also learned about internal professionalism within myself. Like, what does it mean for me to be all these different things at once?" and "How do I access that?" I don't have to be. . I mean, yes, I'm a biology major. That's what I'll graduate with, but I'm not just a bio major." Although it is a logical finding, we did not explicitly teach students how to be creative, yet they valued that they "learned to be creative". Surprisingly to us, many students were previously unaware of their creative abilities. They delighted in their growing creativity, stating that, "I've always never really thought of myself as creative and I guess being a science major people don't think of you as creative when you tell them that."

There were some skills we deliberately tried to teach, that were unmentioned in the themes from student comments. Most glaringly, no students noted valuing the legal and ethical aspects of working with novel technologies. As instructors, we noted student growth in this area during the oral final. We also observed students make gains on these topics in their course journals. This leaves us to wonder whether students did not value the growth in these areas. Perhaps our prompt was not appropriate to demonstrate growth on these topics. We hypothesize that students are so focused on the more tangible skills that they are unable to articulate their own growth in the complex areas of ethical and legal reasoning.

\section{Lessons Learned}

Overall, the course has been very successful and embraced by the students and University administration. Students appreciate the opportunity to work with others from a different profession. This not only helps them develop confidence in their abilities, but they also begin to appreciate the ideas of others, especially from those outside their discipline. Reflecting weekly in 
a journal was valued as well. It gave students an opportunity to think about experiences and digest them better leading to deeper learning or meaning making. University administration recognizes the value of the course and has annually attended the community showcase, as well as showcased it to College level advisory committees. Progress is being made toward supporting faculty in teaching the course. The following lists summarized what has and has not worked well for the course.

What worked well for the course:

- Teaching the course in a MakerSpace environment was neutral territory - not one discipline felt ownership of the space

- Dedicated open hours in the MakerSpace with technical staff for students in the course this increased engagement with the technologies

- The challenge of metabolic syndrome was big and messy enough that teams could pursue a variety of solutions while leveraging strengths from each discipline

- Guest lectures from community partners on topics outside of nursing, biology, and engineering - example: how to sell your idea from a local VC

- Multiple short texts that emphasize the major aspects of the course

- Using an empathy-based design process as the framework for innovation

- Equal representation of disciplines in the mixed teams and teaching team - this also meant that some faculty were teaching an overload

- Holding the course once a week for a 3 hour block of time

- Creativity and team problem solving exercises each class

Opportunities for improvement:

- Expecting that all disciplines would contribute equally without guidance - in the second iteration we added more content on prototyping for the non-engineers and more about metabolic syndrome for the engineers

- Building the connection between innovation and ethics - in the second iteration of the course the ethics discussion was formalized into a lecture that included guided discussion prompts

- Focusing too much on the business case (i.e., calculating estimated costs) was daunting to the student teams and they lost focus

- Instructors assumptions that students would be able to effectively interview people

\section{Conclusions and Future Work}

The Interprofessional Innovations course brings together pre-professional, pre-nursing, and engineering students to leverage maker technology to produce and communicate solutions to the community health challenge of metabolic syndrome. Instructors serve as facilitators and guides while students work to develop solutions. This process ensures that students have ownership of their project as an engaged team and that students grow in their problem-solving, and collaboration skills. The course is taught in a MakerSpace to foster creative problem solving, collaboration skills, and knowledge of technologies that may shape their professions' future. Students work in mixed teams throughout the semester using MakerSpace technologies to prototype solutions to the problem they defined. The final assessment for the student teams is a 
pitch to the community about their idea for addressing issues related to metabolic syndrome with a beta prototype and poster explaining their process.

This course helps students develop creative problem solving, empathetic design practices, interprofessional communication skills, and prototyping skills. Each class opens with a creativity exercise and closes with a creativity exercise that involves team building. Students are expected to become proficient at the empathetic design process as well as interprofessional communication. Creative problem solving and realization of a product through prototyping are expected to be emerging skills that will need further refinement after the course. Following institutional review board approval, research was conducted with consenting participants from the course using qualitative content analysis of student responses to prompts with the aim of assessing course outcomes. Results indicate that the multidisciplinary experience and use of and maker technologies enhance student learning and engagement, foster teamwork and interprofessional skills, and increase students' ability to innovate.

The benefits of the research as a whole may facilitate interprofessional courses and science in the future, as well as help the researchers to discern the most appropriate constructs to measure future offerings of the course. Moreover, these findings address a gap in the available knowledge and literature on interprofessional learning and, thus, can benefit future students, teachers, and researchers.

\section{Acknowledgements}

This work is supported by the 4-VA Collaborative at James Madison University.

\section{References}

1. National Academy of Engineering (NAE), The Engineer of 2020: Visions of Engineering in the New Century 2004, Washington, DC: The National Academies Press.

2. Friedman, T., The World is Flat: A Brief History of the 21st Century 2005, New York, NY: Farrar, Straus, and Giroux.

3. Adams, R.S., L. Mann, and T. Forin., Cross disciplinary practice in engineering contexts, in Proceedings of the International Conference on Engineering Design (ICED)2009: Stanford, CA.

4. Adams, R.S., et al., Exploring student differences in formulating cross-disciplinary sustainability problems. International Journal of Engineering Education, 2010. 26(2): p. 234-338.

5. WHO, 2010

6. National Academy of Engineering. "Grand Challenges for Engineering." Retrieved from http://www.engineeringchallenges.org/

7. National Research Council. Committee on the Robert Wood Johnson Foundation Initiative on the Future of Nursing, at the Institute of Medicine; Institute of Medicine. The Future of Nursing: Leading Change, Advancing Health. Washington, DC: The National Academies Press, 2009. Retrieved from http://books.nap.edu/openbook.php?record_id=12956\&page $=\mathrm{R} 1$

8. American Nurses Credentialing Center. (2008). Magnet Recognition Program Model. http://www.nursecredentialing.org/Magnet/ProgramOverview/New-Magnet-Model. 
9. Peterson, P. A., Keller, T., Way, S. M., \& Borges, W. J. (2015) Autonomy and empowerment in advanced practice registered nurses: Lessons from New Mexico. Journal of the American Association of Nurse Practitioners. Jul2015, Vol. 27 Issue 7, p363-370. 8p.

10. Kihye, H., Trinkoff, A. M., Gurses, A.P. (2015). Work-related factors, job satisfaction and the intent to leave the current job among United States nurses. Journal of Clinical Nursing. Vol. 24 Issue 21/22, p3224-3232.

11. McClelland, M. \& Kleinke, D. (2013). Improving lives using multidisciplinary education: Partnering to benefit community, innovation, health, and technology. Journal of Nursing Education, 52(7), 405-409.

12. Spoelstra, H., Stoyanov, S., Burgoyne, L., Bennett, D., Sweeney, C., Drachsler, H., Vanderperren, K., Van Huffel, S., McSweeney, J., Shorten, G., O’Flynn, S., CantillonMurphy, P., \& O'Tuathaigh, C. (2014). Convergence and translation: Attitudes to interprofessional learning and teaching of creative problem-solving among medical and engineering students and staff. BMC Medical Education, 14(14). doi:10.1186/1472-692014-14.

13. Ness, R. B. (2011). Commentary: teaching creativity and innovative thinking in medicine and health sciences. Academic Medicine, 86, 1201-1203.

14. Norgaard, B., Braborg, E., Vestergaard, E., Odgaard, E., Jensen, D.C., \& Sorensen, J. (2013). Interprofessional clinical training improves self-efficacy of health care students. Medical Teaching, 35(6).

15. Tofil, N. M., Morris, J. L., Peterson, D. T., Watts, P., Epps, C., Harrington, K. F., Leon, K., Pierce, C., \& White, M. L. (2014). Interprofessional simulation training improves knowledge and teamwork in nursing and medical students during internal medicine clerkship. Journal of Hospital Medicine, 9(3), 189-192.

16. Lyons, K.J. (2012). Interprofessional education and training. Retrieved from: http://www.iom.edu/ /media/Files/Activity\%20Files/Workforce/ AlliedHealthWorkshop/12\%20-\%20Lyons.pdf

17. Reeves, S., Goldman, J., Burton, A., \& Sawatzky-Girling, B. (2010). Synthesis of systematic review evidence of interprofessional education. Journal of Allied Health, 39(Suppl. 1), 198-203.

18. Schmutz, J. \& Manser, T. (2013). Do team process really have an effect on clinical performance? A systematic literature review. British Journal of Anesthesia, doi:10.1093/bja/aes513.

19. Winters, C. (2013). Interprofessional education: A CNL-engineer partnership. Communicating Nursing Research, 46, 190-190.

20. Kotche, M., \& Tharp, S. (2015, June), Interdisciplinary Medical Product Development Senior Capstone Design Paper presented at 2015 ASEE Annual Conference \& Exposition, Seattle, Washington. 10.18260/p.24350

21. Sanders, R. \& Geist, M. (2016) Development and Implementation of an Interdisciplinary Course at the Interface of Chemical Engineering and Nursing. Paper presented at 2016 ASEE Southeast Section Conference, Tuscaloosa, Alabama.

22. Reid, K., \& Montenery, S. M., \& Hetrick, C. M. (2011, June), An Innovative Interdisciplinary Student Project: Engineering and Nursing Paper presented at 2011 ASEE Annual Conference \& Exposition, Vancouver, BC. 
23. Bowie, D., \& Xu, X., \& Donaldson, A. L. (2014, June), Teaching Engineering Project Management via Capstone Designs that Develop a Viable Product Paper presented at 2014 ASEE Annual Conference \& Exposition, Indianapolis, Indiana.

24. Nasir, M., \& Kleinke, D. K., \& McClelland, M. (2016, June), Multidisciplinary PatientCentered Capstone Senior Design Projects Paper presented at 2016 ASEE Annual Conference \& Exposition, New Orleans, Louisiana.

25. Rust, M. J., \& Northrup, S. G. (2012, June), Implementation of an International Health Assessment with a Multidisciplinary Team of Undergraduate Engineering and Science Students Paper presented at 2012 ASEE Annual Conference \& Exposition, San Antonio, Texas.

26. Kurti, R. S., Kurti, D. L., \& Fleming, L. (2014). The Philosophy of Educational Makerspaces Part 1 of Making an Educational Makerspace. Teacher Librarian, 41(5), 811.

27. Whitmer, S. (2016). "Makerspaces That Set The Stage For Lifelong Learning." Proceedings of the VentureWell Open Conference, Portland, OR.

28. Rath, T., \& Conchie, B. (2009). Strengths based leadership: Great leaders, teams, and why people follow. New York: Gallup Press.

29. Kelley, T., \& Kelley, D. (2013). Creative confidence: Unleashing the creative potential within us all. Crown Business.

30. Lipson, H., \& Kurman, M. (2013). Fabricated: The new world of 3D printing. John Wiley \& Sons.

31. Skloot, R. (2011). The immortal life of Henrietta Lacks. Broadway Books.

32. Vygotsky, L. S. (1978). Mind in society: The development of higher psychological processes. Cambridge, MA: Harvard University Press

33. Von Glasersfeld, E. (1987). Learning as a constructive activity. Problems of representation in the teaching and learning of mathematics, 3-17.

34. Roth, W. M. (1993). Problem-Centered Learning for the Integration of Mathematics and Science in a Constructivist Laboratory: A Case Study. School Science and Mathematics, 93(3), 113-122.

35. Weimer, M. (2002). Learner-centered teaching: Five key changes to practice. John Wiley $\&$ Sons.

36. Doyle, T. (2012). Learner-centered teaching: Putting the research on learning into practice. Stylus Publishing, LLC.

37. Kolb, D. A. (2014). Experiential learning: Experience as the source of learning and development. FT press.

38. Buck Institute for Education (2017) What is Project Based Learning (PBL)? Retrieved from: http://www.bie.org/about/what_pbl

39. Tuckman, B. W. (1965). Developmental sequence in small groups. Psychological bulletin, 63(6), 384.

40. Tuckman, B. W., \& Jensen, M. A. C. (1977). Stages of small-group development revisited. Group \& Organization Studies, 2(4), 419-427.

41. Stanford d.school (2016) The Wallet Project. Retrieved from: https://dschool.stanford.edu/groups/designresources/wiki/4dbb2/the wallet project.html

42. The Madison Collaborative. (2013). The eight key questions handbook. Retrieved from:https://www.jmu.edu/mc/Docs/131101\%208KQ\%20Handout\%20Revision.pdf 
43. The American Heart Association (2017) About Metabolic Syndrome. Retrieved from: https://www.heart.org/HEARTORG/Conditions/More/MetabolicSyndrome/AboutMetabolic-Syndrome UCM 301920 Article.jsp

44. Ludwig, P., Lewis, E., Nagel, J.K.S. (In review) "Student learning outcomes from an interdisciplinary medical innovations course." Submitted September 2016 to the International Journal of STEM Education. 